\title{
Model Pembelajaran Tebak Kata Menggunakan Software Crossword Dalam Pengajaran Mufradat
}

\author{
Rahmi Wiza \\ Universitas Negeri Padang \\ rahmiwiza@fis.unp.ac.id
}

\begin{abstract}
One of the constraints of students in learning Arabic is the lack of vocabulary. Students who have vocabulary memorization will be faster in learning Arabic lessons. One model of learning in teaching vocabulary is to use the word guessing model. The media used in studying mufradat/vocabulary should be easy, interesting and efficient to use. Educators are asked to be creative in presenting the media used by students. Crossword software is an application that can be used in making vocabulary learning media. This application can help educators in making crossword puzzles and guess words automatically, so the making of media for vocabulary teaching does not take too long and think hard because it is made manually. This application can automatically compile words that match the questions and answers provided by educators. Cross-sectional media or guess words, not only can be used when Arabic lessons take place in class but can be done independently by students. For educators making variations in presenting the form of questions is something that must be considered, so that students become interested and feel happy to use this media.
\end{abstract}

Keywords: Guess Words, Crossword Software, Vocabulary

\begin{abstract}
Abstrak
Salah satu kendala peserta didik dalam mempelajari bahasa Arab adalah kekurangan kosakata. Peserta didik yang memiliki hafalan kosakata akan lebih cepat dalam mempelajari pelajaran bahasa Arab. Salah satu model pembelajaran dalam mengajarkan kosakata adalah dengan mempergunakan model tebak kata. Media yang digunakan dalam mempelajari mufradat/kosakata hendaklah mudah, menarik dan efisien digunakan. Pendidik diminta untuk kreatif dalam menyuguhkan media yang digunakan pada peserta didik. Software Crossword adalah aplikasi yang dapat digunakan dalam pembuatan media pembelajaran kosakata. Aplikasi ini dapat membantu pendidik dalam membuat teka teki silang dan tebak kata secara
\end{abstract}


otomatis, sehingga pembuatan media untuk pengajaran kosakata tidak terlalu membutuhkan waktu yang panjang dan berfikir keras karena dibuat secara manual. Aplikasi ini secara otomatis dapat menyusun kata yang sesuai dengan soal dan jawaban yang telah disediakan oleh pendidik. Media teka teki silang atau tebak kata, tidak hanya dapat digunakan saat pelajaran bahasa Arab berlangsung di kelas namun dapat dikerjakan secara mandiri oleh peserta didik. Bagi pendidik membuat fariasi dalam menyuguhkan bentuk soal merupakan hal yang harus diperhatikan, sehingga peserta didik menjadi tertarik dan merasa senang menggunakan media ini.

Kata Kunci: Tebak Kata, Software Crossword, Mufradat

\section{Pendahuluan}

Sarinah Hardjono menyatakan bahwa dari semua aspek bahasa asing yang dianggap paling penting dan harus dikuasai peserta didik dalam proses belajar mengajar bahasa asing adalah aspek kosakata. ${ }^{1}$ Aspek kosakata merupakan permasalahan mendasar bagi peserta didik dalam mempelajari bahasa Arab dan kesulitan dalam penguasaannya, padahal kosakata merupakan modal dasar bagi peserta didik dalam mengembangkan bahasa Arab.

Efek dari kekurangan kosakata ini berimbas pada perspektif peserta didik yang menyatakan bahwa bahasa Arab adalah bahasa yang sulit untuk dipelajari atau dipahami sehingga timbul rasa pesimis untuk mempelajari apalagi menguasainya. Sebagaimana pendapat Rusydi Ahmad Thu'aimah bahwa seseorang tidak dapat menguasai bahasa sebelum menguasai kosakata bahasa tersebut. $^{2}$

Menurut Brown, mempelajari bahasa kedua adalah pekerjaan panjang dan kompleks. Manusia akan berjuang melampaui batasan-batasan bahasa pertama dan berusaha menggapai sebuah bahasa baru, budaya baru, dan cara baru dalam berpikir, merasakan dan bertindak. ${ }^{3}$ Dengan demikian mempelajari bahasa membutuhkan metode khusus agar saat peserta didik mempelajari sebuah bahasa tidak memiliki kendala untuk mengembangkan bahasa tersebut.

Permasalahan yang timbul dalam proses pembelajaran merupakan sebuah permasalahan yang harus dicarikan solusinya oleh pendidik, sehingga pelajaran yang disampaikan diterima peserta didik dengan baik, karena pendidik adalah fasilitator dalam penyampaian sebuah ilmu dan diharapkan untuk berjiwa kreatif,

\footnotetext{
${ }^{1}$ Sartinah Hardjono, Psikologi Belajar Mengajar Babasa Asing, (Jakarta: Depdikbud, 1988). hlm. 71

${ }^{2}$ Rusydi Ahmad Thu'aimah, Ta'lim al-'Arabiyah li Ghair al-Nâthiqina Biha: Manâhijuha wa Asâlibuba, (Rabath: Isesco, 1989), hlm. 194

${ }^{3}$ H. Douglas Brown, Prinsip Pembelajaran dan Pengajaran Bahasa, Edisi Kelima, (San Fransisco: Pearson Education Ltd, 2007), hlm. 1
} 
efektif dan inofatif dalam menyajikan pelajaran dengan memanfaatkan kondisi, media dan metode yang sesuai dengan keadaan peserta didik. Bukan hanya itu, proses pengajaran hendaklah menyenangkan dan membuat peserta didik aktif serta tujuan pelajaran tetap tersampaikan.

Secara umum tujuan pengajaran mufradat adalah: 1. Memperkenalkan kosakata baru kepada peserta didik. 2. Melatih peserta didik untuk dapat melafalkan kosakata itu dengan baik dan benar sehingga mengantarkan kepada kemahiran berbicara dan membaca secara baik dan benar. 3. Memahami makna kosakata, baik secara denotasi atau leksikal maupun ketika digunakan dalam konteks kalimat tertentu. 4. Mampu mengapresiasi dan memfungsikan mufradat itu dalam berekspresi lisan maupun tulisan sesuai dengan konteksnya. ${ }^{4}$ Dengan memperhatikan tujuan tersebut maka diharapkan peserta didik memiliki modal dasar dan dapat mengembangkannya pada tahap pembelajaran bahasa Arab selanjutnya.

Melihat tujuan umum dari pengajaran mufradat tersebut, maka dibutuhkan metodologi yang tepat. Sebagaimana pernyataan Muljianto Sumardi, bahwa salah satu aspek yang menentukan keberhasilan pengajaran bahasa Arab khususnya dalam pengajaran kosakata ini adalah aspek metodologi. Sebab metodelah yang menentukan isi dan cara mengajar. ${ }^{5}$ Dalam metodologi pengajaran terdapat dua aspek yang menjadi perhatian penting yakni metode mengajar dan media pengajaran sebagai alat bantu mengajar. Media pengajaran yang digunakan dapat berbagai ragam dan bentuk, baik dalam bentuk visual maupun audio visual dan yang terpenting media tersebut mudah, menarik dan efisien untuk digunakan.

Diantara bentuk media yang dapat digunakan pendidik dalam pengajaran mufradat adalah tebak kata. Pengajaran tebak kata dapat mengaktifkan indera peserta didik dari segi visual, audio visual, dan kinestetik. Bukan hanya sekedar melihat media yang disampaikan, tapi peserta didik diarahkan untuk berusaha mengucapkan kata yang benar dengan cara menebak kemudian menulis kata tersebut. Ini merupakan salah satu metode untuk membuat pengajaran bahasa Arab menjadi menarik dan tidak membosankan.

\section{Pembahasan}

\section{Model Pembelajaran Tebak Kata}

Model pembelajaran tebak kata dapat dikategorikan pada permainan bahasa. Fathul Mujib dan Nailur Rahmawati menyatakan, bahwa untuk dapat

\footnotetext{
${ }^{4}$ Syaiful Mustofa, Strategi Pembelajaran Babasa Arab Inovativ, (Malang: UIN Press, 2011), hlm. 79

5 Muljianto Sumardi, Pengajaran Bahasa Asing: Sebuah Tinjanan dari Segi Metodologis, (Jakarta: Bulan Bintang, 1974), hlm. 7
} 
disebut sebagai permainan bahasa, harus memenuhi dua syarat, yaitu menggembirakan dan melatih keterampilan berbahasa. ${ }^{6} \mathrm{Hal}$ ini berarti pada saat proses belajar peserta didik tidak merasa tertekan karena suasana belajar yang menyenangkan sehingga memiliki kesan tersendiri dan tujuan dari sebuah pembelajaran tercapai dengan baik yaitu keterampilan berbahasa peserta didik meningkat baik dari aspek keterampilan mendengar, berbicara, membaca atau menulis.

Diantara beberapa bentuk model pengajaran tebak kata yaitu:

1. Teka Teki Silang (TTS)

Permainan teka teki silang dimainkan dengan cara mengisi kotak kosong dengan rangkaian beberapa huruf pada setiap kotak yang merupakan jawaban dari soal yang telah disediakan. Dalam bahasa Inggris teka teki silang dikenal dengan Crossword dan dalam bahasa Arab disebut dengan لغز الكلمات المتقاطعة.

Berdasarkan sejarah, 7 Teka Teki Silang ditemukan oleh Arthur Wynne, lahir di Liverpool Inggris pada tanggal 22 Juni 1871. Saat masih kanak-kanak ia bersama orang tuanya migrasi ke Piitsburgh, Pennsylvania, Amerika Serikat dan menghabiskan masa dewasanya di kota ini. Arthur memiliki beberapa hobi, selain bermain biola dan bergabung dengan Pittsburgh Orchestra, ia juga tertarik dengan dunia jurnalis dan bergabung dengan koran lokal Pittsburgh Press.

Dari Pittsburgh, ia pindah ke Cedar Grove, New Jersey dan bekerja pada koran New York World yang berbasis di News York City, di koran inilah ia menuangkan ide membuat teka teki silang untuk menghibur para pembaca. Permainan ini diadopsi dari permainan kuno bernama Pompeii yang berarti Magic Square (dalam bahasa Inggris). Dan Untuk pertama kalinya teka teki silang karya Arthur di publikasikan pada edisi akhir pekan, Minggu, 21 Desember 1913.

Sejak diterbitkan di Amerika, teka teki silang menjadi inspirasi media massa di Inggris, seperti majalah Pearson, menerbitkan teka teki silang pertama kali pada edisi Februari 1922. Bukan hanya di koran dan majalah, teka teki silang juga dijadikan buku tersendiri atas kerjasama Dick Simon dan Lincoln Schuter tahun 1924 dan diberi nama The Cross Word Purale Book.

Pada tahun 1997 pada era modern, perusahaan game digital Variety Games Inc membuat software komputer pembuat teka teki silang dan dipatenkan sebagai software program teka teki silang pertama di dunia. Hingga saat ini permainan teka teki silang atau crossword ini masih populer dan digunakan oleh banyak orang untuk mengisi waktu luang dan beberapa manfaat lainnya.

\footnotetext{
${ }^{6}$ Fathul Mujib dan Nailur Rahmawati, Permainan Edukatif Pendukung pembelajaran Bahasa Arab 2, (Jogjakarta: Diva Press, 2012), hlm. 39-41

${ }^{7}$ www.putramelayu.web.id/2013/07/sejarah-lahirnya-teka-teki-silang-tts.html
} 


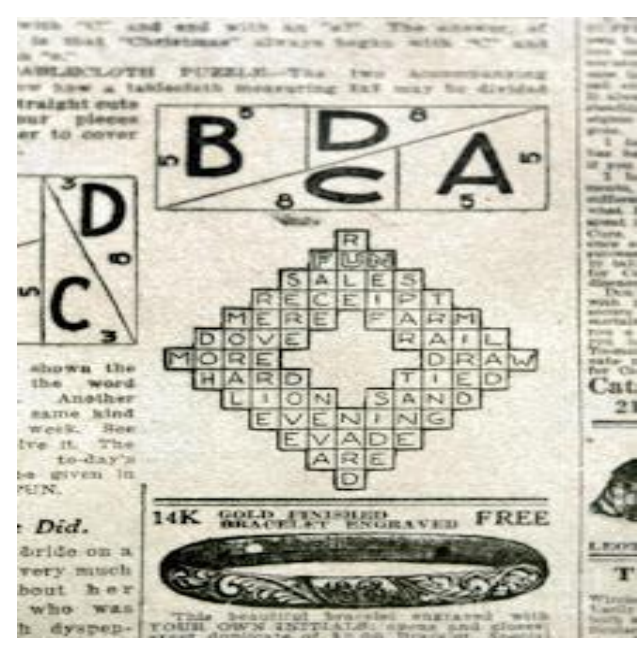

Contoh teka teki silang pertama kali di dunia

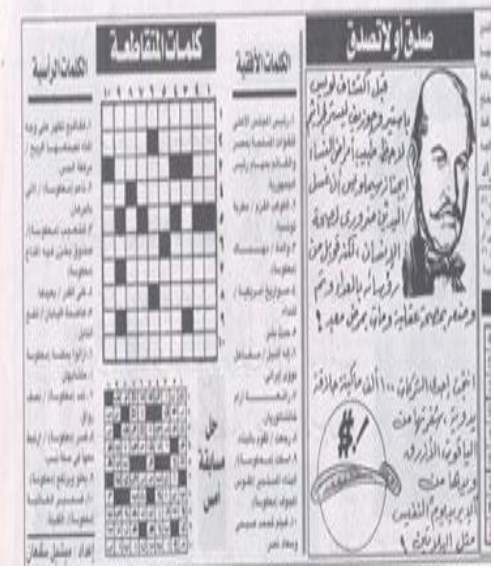

Contoh teka teki silang yang tersebar di Timur Tengah

Teka teki silang ini bukan hanya dapat dinikmati oleh khalayak umum untuk mengisi waktu luang saja, namun juga dapat dijadikan sebagai salah satu media pengajaran oleh pendidik untuk mengajarkan pelajaran mufradat yang tidak membosankan, cara penyajian pun bisa dimodifikasi sesuai dengan kreatifitas pendidik, sehingga peserta didik memiliki minat yang tinggi dalam mengerjakannya, baik di lingkungan sekolah maupun di luar sekolah.

2. Word Search/tebak kata.

Word search merupakan permainan mencari kata pada kotak yang berisi puluhan huruf yang tersusun secara acak. Media word search, memiliki beragam cara pengerjaan bagi peserta didik, sedikit berbeda dengan teka teki silang yang mengisi kotak kosong hanya tersusun secara vertikal dan horizontal, word search dapat disusun dalam bentuk simetris.

3. Menentukan kosakata dalam gambar.

Media ini disajikan dengan cara menyediakan gambar yang di dalamnya terdapat benda-benda dalam sebuah ruangan atau lingkungan, atau menyajikan sebuah kegiatan, kemudian peserta didik menentukan kosa kata yang terdapat di dalam gambar.

4. Mencari pasangan antara soal dan jawaban.

Media ini dibuat dengan cara memisahkan antara soal dan jawaban pada tempat yang berbeda, peserta didik diminta untuk menentukan pasangan dari soal dan jawaban yang cocok. Soal dan jawaban bisa di fariasikan dalam bentuk tulisan, gambar atau angka sesuai dengan materi yang akan diajarkan oleh pendidik. 


\section{Aplikasi Crossword}

Di zaman era modern, sistem pengajaran tidak lepas dari media elektronik. Media ini dapat membantu pendidik dalam membuat media yang akan disajikan kepada peserta didik. Kreatifitas yang tidak didukung dengan kemahiran yang sesuai dengan kemajuan zaman akan menyulitkan pendidik dan media yang dihasilkan akan kurang menarik karena dibuat secara manual.

Aplikasi crossword adalah software yang bertujuan untuk membuat teka teki silang. Aplikasi ini dapat membantu pendidik dalam membuat media teka teki silang, tidak membutuhkan waktu yang cukup lama untuk berfikir dalam menyusun huruf yang akan disajikan dalam media, crossword sudah menyajikan secara otomatis bentuk susunan huruf yang akan dikerjakan oleh peserta didik. Tugas seorang pendidik hanya memasukkan jawaban dan soal pada kolom yang disediakan kemudian memilih tipe dari permaian, baik crossword silang atau word search.

Penggunaan aplikasi crossword ini dapat didownload baik secara gratis maupun berbayar lewat internet. Kelebihan dari aplikasi ini adalah penghematan waktu dan biaya dalam pengerjaan media teka teki silang, pendidik tidak perlu berfikir secara keras dalam menyusun huruf, cukup dengan mengoperasikan aplikasi yang ada dan mengikuti instruksi yang ada dan disertai dengan pengaturan yang dibutuhkan. Bukan hanya dalam pembuatannya saja, saat di print pun ada pilihan baik berupa lembaran yang memiliki kunci jawaban (pegangan untuk pendidik), atau dalam bentuk lembaran yang hanya terdapat soalnya saja (dibagikan untuk peserta didik).

Dalam penyajian media teka teki silang dalam aplikasi crossword khusus untuk bahasa Arab, pengaturan yang harus diperhatikan adalah pengaturan bahasa yang diubah ke dalam bahasa Arab karena soal dan jawaban terdiri dari bahasa arab, tidak semua aplikasi yang dapat membaca tulisan bahasa Arab, sehingga pastikan mengunduh aplikasi yang dapat menggunakan bahasa Arab. Susunan huruf dalam kotak pun harus diatur dari kanan ke kiri, karena aplikasi awal hanya menampilkan bentuk susunan huruf dari kiri ke kanan. Hal ini di perlukan agar saat pendidik memasukkan kunci jawaban dari soal yang disediakan tidak mengalami kesulitan.

Dalam lembaran kerja yang dibagikan kepada peserta didik, jangan lupa untuk mengimbuhkan tema yang dibahas dan instruksi dalam pengerjaan soal. Masukkan soal dan jawaban sesuai dengan tema yang akan dibahas. Tentukan jenis pengerjaan soal, crossword atau word search, saat menekan tombol make puzzle dalam pembuatan media, pendidik dapat memilih model susunan teka teki silang yang telah disediakan secara otomatis, sehingga satu tema dapat dibuat dalam bentuk model susunan huruf yang berbeda-beda. 
Lembaran latihan yang dikerjakan oleh peserta didik adalah lembaran latihan yang masih kosong, sedangkan yang memiliki kunci jawaban di pegang oleh pendidik. Pengerjaan crossword atau word search, dapat dilakukan secara individu atau berkelompok oleh peserta didik.

Contoh media crossword:

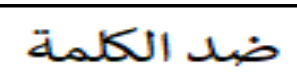

! إكر ضا الكلمات الآتية
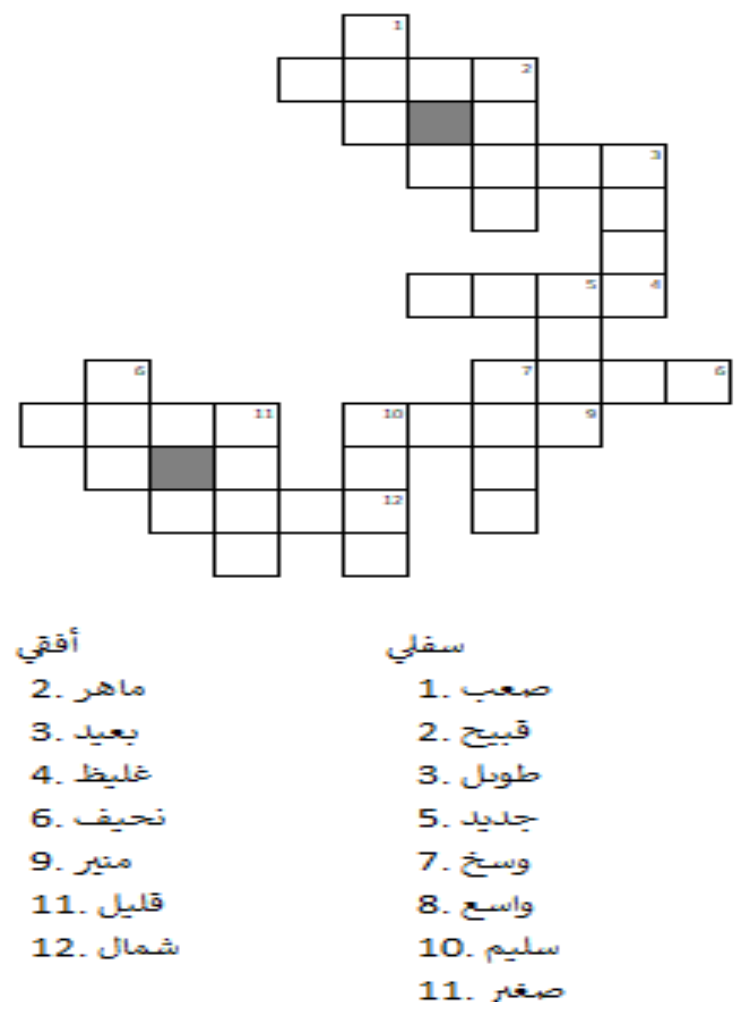

Contoh media word search, yang diberikan kepada siswa adalah lembaran latihan yang belum ada jawaban yang dilingkari: 


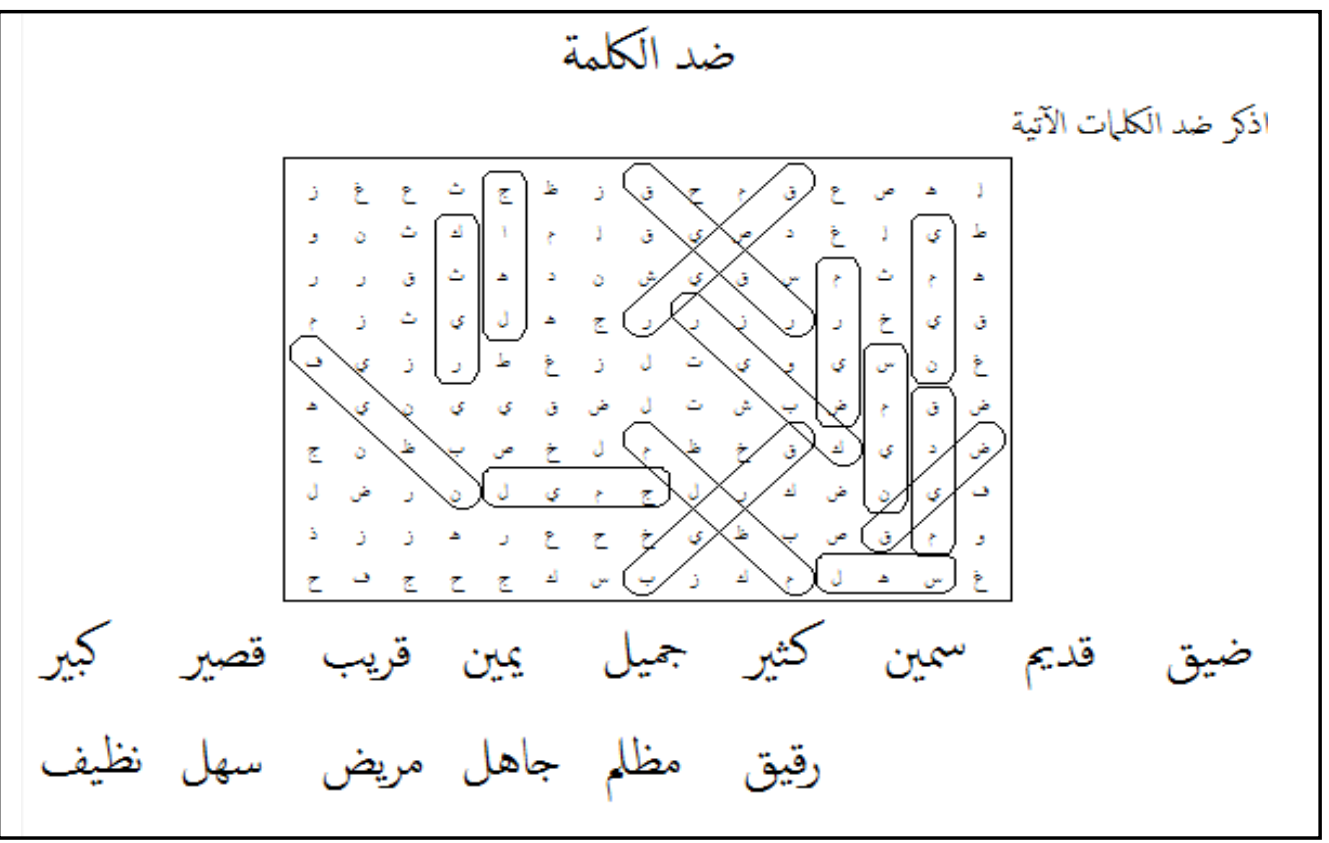

Soal pada crossword atau word search dapat difariasikan berupa:

1. Menentukan kata yang dimulai dengan huruf yang telah disediakan pada setiap awal kotak teka teki silang dan jawaban disesuaikan dengan tema yang telah ditentukan.

2. Menentukan kosakata dari gambar yang disediakan.

3. Menyusun kembali huruf yang disusun secara acak menjadi kata yang benar.

4. Menjawab pertanyaan.

5. Menentukan padanan kata (مرادف).

6. Menentukan lawan kata (ضد).

7. Menentukan bentuk jamak dari kata tunggal atau sebaliknya.

8. Menentukan bentuk mudhari' dari madhi atau sebaliknya.

9. Penjumlahan dari beberapa angka.

Beberapa hal yang harus diperhatikan oleh pendidik dalam pembuatan media ini adalah:

1. Utamakan tema yang berada di sekitar peserta didik, dari yang paling sering di temui/dilakukan sampai yang jarang ditemui. Hal ini berfungsi membantu memudahkan peserta didik untuk menghafal mufradat secara langsung.

2. Mengutamakan untuk menggunakan kata yang berbentuk isim/kata benda terlebih dahulu, jangan mencampur antara isim dan fi'il/ kata kerja. Walaupun Kata dalam bahasa arab terbagi kepada tiga: isim, fi'il dan burf, kelompokkan dalam satu tema untuk kata benda saja kemudian baru berpindah pada kata kerja, hal ini bertujuan agar peserta didik dapat fokus 
dalam mengahafal mufradat. Dan pendidik pun dapat dengan mudah mengelompokkan sebuah kata.

3. Memperhatikan tingkat level kesulitan teka teki silang yang sesuai dengan keadaan peserta didik, dari level mudah, sedang sampai level sulit.

4. Menargetkan alokasi waktu yang digunakan, dengan membatasi jumlah soal yang diberikan sehingga tujuan dari pelajaran tersampaikan.

5. Membuat aturan-aturan dalam pengajaran penggunaan media ini agar kelas terkelola dengan baik dan tidak menggangu kelas yang berada disampingnya.

6. Mengajak seluruh peserta didik untuk aktif dan mengikuti setiap instruksi yang diberikan oleh pendidik.

7. Permainan dapat dimulai jika peserta didik telah memahami instruksi pengisian media dan memahami aturan-aturan yang diberikan.

8. Pendidik harus menyimpulkan kembali pelajaran yang telah diberikan, dan menghubungkan dengan materi sebelumnya.

Contoh Alokasi waktu yang harus ditetapkan oleh pendidik:

\begin{tabular}{|l|l|}
\hline Jenis Kegiatan & Uraian \\
\hline Pendahuluan (2 mnt) & $\begin{array}{l}\text { Peserta didik masuk kelas dan meminta peserta didik } \\
\text { untuk membaca do'a }\end{array}$ \\
\hline Pelaksanaan: & Pendidik menunjukkan lembaran latihan dalam \\
Langkah 1 & bentuk teka teki silang. \\
& Pendidik menjelaskan cara permainan, dan instruksi \\
dalam pengerjaannya. & Pendidik menjelaskan tema yang akan dibahas dalam \\
& teka teki silang. \\
& Pendidik meminta peserta didik menyebutkan \\
& beberapa contoh kata yang terdapat di dalam tema \\
& yang akan digunakan. \\
& Pendidik menjelaskan bentuk kata yang akan diisikan \\
& dalam teka teki silang (ism atau fi'i). \\
& Pendidik memberi kesempatan untuk bertanya kepada \\
& peserta didik seputar tema atau instruksi dalam \\
pengerjaan media teka teki. & Pendidik menekankan kembali peraturan dalam \\
& pengerjaan media teka teki silang \\
\hline
\end{tabular}




\begin{tabular}{|c|c|}
\hline $\begin{array}{l}\text { Langkah } 2 \\
\text { (30 menit) }\end{array}$ & $\begin{array}{l}\text { Pendidik meminta peserta didik untuk duduk secara } \\
\text { berkelompok. } \\
\text { (Pengerjaan lembar latihan dapat dilakukan secara } \\
\text { berkelompok atau perorangan). } \\
\text { Pendidik mengedarkan lembaran kerja kepada } \\
\text { peserta didik yang berisi crossword atau research } \\
\text { word. } \\
\text { Pendidik memberikan waktu kepada peserta didik } \\
\text { untuk mengerjakan lembaran kerja tersebut dan } \\
\text { diperbolehkan melihat kamus dan alat bantu lainnya. }\end{array}$ \\
\hline $\begin{array}{l}\text { Penutup: } \\
\text { (40 menit) }\end{array}$ & $\begin{array}{l}\text { Pendidik meminta semua peserta didik untuk } \\
\text { memperhatikan lembaran kerja yang telah dikerjakan } \\
\text { secara berkelompok atau perorangan. } \\
\text { Pendidik membahas kosakata dalam media lembar } \\
\text { kerja. } \\
\text { Peserta didik diberikan kesempatan untuk menjawab } \\
\text { soal secara bergantian. } \\
\text { Peserta didik yang lain diberi kesempatan untuk } \\
\text { membetulkan jawaban yang salah. } \\
\text { Pendidik memberikan kunci jawaban setiap soal yang } \\
\text { telah disediakan. } \\
\text { Pendidik dapat menghubungkan pelajaran mufradat } \\
\text { ini dengan materi pelajaran sharf yang masih umum, } \\
\text { seperti menentukan benda yang muzakkar atau } \\
\text { muannas, bentuk mufrad, mutsanna atau jama' sebuah } \\
\text { kata dan lain-lain. }\end{array}$ \\
\hline
\end{tabular}

Kelebihan dan kekurangan dalam menggunakan Metode Tebak Kata.

1. Kelebihan

a. Media ini dapat mengaktifkan peserta didik di dalam lokal, apalagi kalau di dukung dengan panduan pendidik.

b. Media ini melibatkan aktifitas fisik dan mental peserta didik.

c. Meningkatkan daya ingat otak.

d. Suasana belajar menjadi menyenangkan.

e. Dapat mengerjakan lembaran latihan sendiri di rumah

f. Mencegah kepikunan dini.

g. Mengusir rasa jenuh dan membuat peserta didik bersemangat untuk belajar di lokal.

h. Terbinanya kerjasama antara peserta didik dalam kelompok.

i. Pelajaran yang menyenangkan akan menjadi kesan baik bagi peserta didik. 
j. Media ini dapat mengasah kemahiran peserta didik untuk membaca, berkata dan menulis.

k. Menjadikan kedekatan antara pendidik dan peserta didik.

2. Kekurangan

a. Peserta didik yang berjumlah terlalu besar dapat mengganggu proses kegiatan karena tidak semua dapat dilibatkan.

b. Pelaksanaan kegiatan dapat menimbulkan suara gaduh dan gelak tawa sehingga dapat mengganggu kelas lain

c. Tidak semua materi dapat dikomunikasikan dengan permainan bahasa.

d. Permainan bahasa masih dianggap sebagai selingan saja.

e. Dalam permainan bahasa, banyak terkandung unsur untung-untungan sehingga tak dapat digunakan untuk menilai hasil belajar. 8

f. Bentuk soal yang monoton atau tanpa fariasi akan membuat peserta didik menjadi jenuh.

g. Pengajaran yang tidak memiliki aturan-aturan dalam pengajaran lokal, membuat lokal menjadi ribut dan tidak terkendali.

\section{Penutup}

Keberhasilan dalam mendapatkan sebuah ilmu bagi peserta didik dipengaruhi oleh faktor internal dan faktor eksternal. Media pembelajaran merupakan salah satu faktor eksternal penunjang keberhasilan dalam proses pembelajaran.

Dalam pembelajaran Bahasa Arab, model pengajaran tebak kata merupakan sebuah model alternatif yang digunakan oleh pendidik. Media yang digunakan dapat disajikan dalam beragam bentuk, diantaranya teka teki silang. Untuk membantu pendidik dalam membuat media ajar teka teki silang, dapat menggunakan Software Crossword. Selain membantu pendidik dalam membuat media, aplikasi ini juga menyuguhkan beberapa model teka teki silang yang dapat dipilih oleh pendidik sehingga media yang disajikan menarik dan jauh dari kesalahan karena pengerjaannya dilakukan secara otomatis.

Penggunaan media teka teki silang dapat menciptakan lingkungan belajar yang aktif dan nyaman karena bukan hanya di kelas, peserta didik dapat menyelesaikan soal yang terdapat pada media di luar kelas. Peserta didik tidak tidak akan merasa jenuh dan bosan dengan soal yang berfariasi.

Dari pengajaran tebak kata ini, peserta didik bukan saja dapat meningkatkan kemampuan dalam menghafal kosakata, tapi juga mempermudah pendidik untuk mengajarkan cabang ilmu bahasa arab seperti ilmu sharf dan ilmu nahwu.

\footnotetext{
${ }^{8}$ Soeparno, Media Pengajaran Bahasa, (Yogyakarta: PT. Intan Pariwara, 1988), hlm. 63
} 


\section{Bibliografi}

Brown, H. Douglas. Prinsip Pembelajaran dan Pengajaran Bahasa, Edisi Kelima. San Fransisco. Pearson Education Ltd. 2007.

Efendy, Ahmad Fuad. Metodologi Pengajaran Bahasa. Malang. Misykat. 2014

Hardjono, Sartinah. Psikologi Belajar Mengajar Bahasa Asing. Jakarta. Depdikbud. 1988.

Mustofa, Syaiful. Strategi Pembelajaran Bahasa Arab Inovativ. Malang. UIN Press. 2011.

Mujib, Fathul dan Nailur Rahmawati. Permainan Edukatif Pendukung pembelajaran Bahasa Arab 2. Jogjakarta. Diva Press. 2012.

Sumardi, Muljianto. Pengajaran Bahasa Asing: Sebuah Tinjauan dari Segi Metodologis. Jakarta. Bulan Bintang. 1974.

Thu'aimah, Rusydi Ahmad. Ta'lim al-'Arabiyah li Ghair al-Nâthiqîna Biha: Manâhijuha wa Asâlibuha. Rabath. Isesco. 1989.

Soeparno. Media Pengajaran Bahasa. Yogyakarta. PT. Intan Pariwara. 1988.

www.putramelayu.web.id/2013/07/sejarah-lahirnya-teka-teki-silang-tts.html 